\title{
INVESTIGATING THE EFFECT OF BUSINESS STRATEGY AND INTERNAL CONTROL ON AUDIT QUALITY \\ Mohammad Vahdani ${ }^{1}$, Rozhan Rashedi ${ }^{2}$, Javad Mohammadi Mehr ${ }^{3 *}$
}

${ }^{1}$ Department of Accounting, Faculty of Humanities, University of Bojnord, Bojnord, Iran, ${ }^{23}$ Department of Accounting, Faculty of Humanities, University of Payamnoor, Bojnord, Iran.

Email: ${ }^{1}$ M_vahdani99@yahoo.com, ${ }^{2}$ Rozha.rashedi@yahoo.com, ${ }^{3 *}$ j.mohamadimehr@gmail.com

Article History: Received on $12^{\text {th }}$ October 2019, Revised on $29^{\text {th }}$ November 2019, Published on $19^{\text {th }}$ December 2019

\begin{abstract}
Purpose: Auditing will improve the quality of financial information. However, in today's audit quality affected by the environment. The purpose of this study to investigate the effect of business strategy and internal control on audit quality in listed companies in the Tehran Stock Exchange.
\end{abstract}

Methodology: This is applied research in terms of its purpose and in terms of its method is correlation analysis with the regression approach. For this inference method, this research is descriptive-analytic. For this important statistical society, companies listed in the Tehran Stock Exchange during the years 2010-2017 for 8 years have the necessary conditions. According to the constraints defined in the research, companies with qualifying conditions of 107 companies and 856 years-company of observation were collected. To test the hypotheses, the multivariate regression technique was used using panel data.

Main Findings: The business strategy modifies the relationship between the auditor's specialty in the industry and the internal control of audit quality.

Implications: The control structure can provide an understanding of the difference between the business strategy and its diversion, which is necessary for the auditor's expertise in the industry. It is proposed to combine business strategy and audit planning, we can identify the weakness of the internal control of the system in order to improve the quality of the audit and create value for the stakeholders.

Novelty: The study considered the effects of business strategy on the relationship between internal control and audit quality.

Keywords: Business Strategy, Internal Control, Audit Quality, Industry Auditor's Specialty, Corporate Governance.

\section{INTRODUCTION}

Economic units need to have an internal control system to achieve short-term and long-term goals and fulfill missions and perspectives, maintain financial and profitability, deal with unexpected events and respond to the respondent (capital owners, government). Internal control is not an event or specific situation, but a set of continuous and inclusive actions that extends to all activities of the organization. These actions take place in the context of an organization's operations in a continuous manner. They are in an inclusive and inseparable way in the way that the organization manages (Kinney et al., 2011). What is important is that the auditor needs to have complete information about internal controls and in general, it has weaknesses so that, as soon as they are seen and dealt with, they will take the weaknesses of the internal controls and report them to the unit. Some weaknesses in internal controls exist in most of the units under consideration, and some of the weaknesses are specific to individual treatment units and, therefore, are generally unpredictable and can only be discovered by an in-depth examination of internal control systems (Johnstone \& Colleagues, 2010).

The existence of reports of weaknesses in internal control can provide information users with weaknesses and management practices. In accounting terms, the internal control system imparts an essential mechanism for investors to assess the adequacy of corporate performance reports. For example, an appropriate internal control system will have effective oversight of organizational processes that are critical to achieving good financial reporting objectives (Krishnan, 2003) $)^{23}$. Verschoor (2002) believes that one of the most important reasons for Enron's financial scandal was its weak internal control system .Therefore, factors such as corporate governance mechanisms that affect the quality of internal control will be considered. Kirishnan (2003) Proved that an independent audit committee that is great, is likely to reduce the likelihood of weak internal control. Zhang et al. (2007) also found that both the audit committee and the independent auditor are effective in reducing and improving the weaknesses of the internal control system. Ultimately, Michelonet al (2015) showed an inverse relationship between the results of the disclosure of internal control and the supervisory boards of the board. However, these studies are based on developed countries (eg, the United States, European countries) with high audit infrastructures, regardless of how an audit environment may link the characteristics of corporate governance and the quality of internal control focus. This empirical work examines the relationship between governance characteristics and the weakness of internal control in well-regulated environments such as the United States with developed government practices (Deffond, 2015).

What is important is that the auditor should have complete information about internal controls and weaknesses in general in order to take control of the weaknesses of the internal controls as soon as they are observed and dealt with them. Some 
weaknesses in internal controls exist in most of the units under consideration, and some of the weaknesses are specific to the particular investigation units and, therefore, they are generally unpopular and can only be found by carefully examining the internal control systems (Fakhari and Alizadeh, 2016). The internal control system was designed to assist management in achieving business goals and desirable results (Harmon, 2003). Internal controls are used in a variety of ways according to the business unit strategy (Miller et al., 2012) (n) $^{26}$ Internal control is a process that is designed and implemented by management and other staff to obtain reasonable assurance of achieving the objectives of the unit in the field of effectiveness and productivity of operations, reliability of financial reporting and compliance with laws or rules.

\section{THEORETICAL FOUNDATIONS OF RESEARCH}

Users of financial statements, including investors, credit and financial institutions, banks, government departments, creditors and other stakeholders, attach great importance to the quality of financial information. Shareholders and Board of Directors and the Audit Committee due to reasons such as reducing the cost of capital interested in the quality of financial information and audit. Additionally, regulators and lawmakers can increase the effectiveness of capital markets by promoting rules and regulations; this is through assurance this is because auditing will improve the quality of financial information. However, in today's audited environment, which is somewhat flawed in auditing, there is a great deal of concern about audit quality (Miettinen, 2014), since audit quality is multi-dimensional and inherently unobservable; a single measure for measuring it Does not exist. By combining financial reporting quality measurement criteria, researchers created an indicator for audit quality, arguing that if auditors make high-quality audits, they should also be reflected in the financial statements. The findings of previous research indicate that industry specialist auditors are offering higher quality audit services than auditors who are not industry experts and have a positive relationship between the industry's expertise in auditing and the direct and indirect criteria of audit quality. The use of an expert industry expert with Lower accruals (higher earnings quality) (Krishnan et al., 2003) and higher earnings response rates are associated (Balsam et al., 2011). Strategy theorists believe that internal control systems of companies are different and, given the changing market and business strategy, can be flexible and adapt to the market. For the flexibility of internal control systems, the components of those systems Integrated and coordinated and focused to maximize productivity. Therefore, industry expertise in auditing can open up internal control (Newton et al., 2016). An industry specialist needs to invest heavily and, as a result, it is expensive. In terms of cost-benefit analysis, this investment is justifiable because the audit firm expects this investment to be expected to improve the quality of auditing, attract more customers, and profit from it. The relationship between an industry expert's expertise and audit quality was not prior to the study by Gramlingand Stone (2001). But now a large number of articles have tested the impact of the auditor's specialty on audit quality (Yuana et al., 2016). Several studies have shown that industry-specific auditors can provide higher quality audit services. On the one hand, literature and previous evidence show that business strategy is one of the important factors in the quality of audit (Dichev et al., 2013). Various studies have also shown that strategic risk is an important component of the business audit risk model, and the main objective of the analytical method of auditors is to gain an understanding of the customer's business (Eilifsen et al., 2001). Erickson et al. (2000) attributed the major causes of Lincoln Bank and audit firms to the fact that audit staff did not succeed in acquiring and using the knowledge of the business owner and its compliance with audit procedures. Bentley et al. (2013) presented the first major empirical sample that the business strategy significantly affects the occurrence of financial reporting disorder and audit effort. Consequently, international auditing standards, as well as US standards, require auditors to understand the strategies of their clients and their respective business risks during their planning (Yuana et al., 2016).

The low audit quality resulting from weaknesses in internal control gives the manager the opportunity to provide inaccurate information to customers, which leads to a deviation in the business strategy (Higgins et al., 2015).

In the event that business strategies differ in terms of the level of business risk and the probability of fraudulent financial reporting, in practice, one can expect that the audit firms have different levels of audit engagement based on the business strategy of the unit to study the financial statements of these units (Dhaliwal et al., 2011), besides non-expert auditors in the industry, the strategic deviation of the owner affects the knowledge gains of industry professionals. Although, the customer's strategic deviation may decrease the space between knowledge-based auditors and industry-unskilled auditors, as industry professionals may focus on issues that have already been addressed and for both types of auditors, the deviant strategies of the client are a kind of innovation strategy that they have no experience and expertise in this connection. Hence, experts and non-specialists may lack specific knowledge related to the industry strategy. On the other hand, the strategic deviation of the owner may increase the use of industry-specific knowledge to non-expert auditors. First, industry experts are auditing a variety of business executives from the industry. Hence, they are more likely to face hard-core executives and understand the strategy of the more extreme industry than unskilled auditors. Second, existing literature suggests that industry professionals can better assess business-related risks or strategies related to nonspecialists (Yuana et al., 2016).

Given that industry professionals can better understand the audit risks associated with high-level engagement. Because deviation of the client strategically requires experience and confrontation with similar cases that have already occurred, this suggests that industry-specific auditors can engage in non-expert auditors in risk assessment for strategically Diverted (generally more exposed to higher uncertainty). Fourthly, when auditing clients with highly diverse strategies, non-expert auditors use Industry criteria for evaluating the appropriateness of accounting practices, whilst industry- 
specific auditors able to use their previous experiment with highly diverse customers in order to facilitate their audit. Fifth, deviant strategies are likely to face the problem of information asymmetry, as it is difficult for outsourced users to understand the strategy of those companies and business models. Therefore, non-expert auditors can play a more significant task in this regard. So, customer strategic deviations will increase the gap in the relative consciousness space between non-expert auditors in the industry and non-expert auditors (Kathleen, 2018); the present study discusses several issues related to internal control reporting Take up The business strategy is predicting internal control weaknesses. Understanding a business strategy is to gain insight into the quality of internal control of the company using the expertise of auditors. Therefore, combining business strategy and audit planning due to the expertise of auditors in the industry will improve the quality of internal control. Therefore, the purpose of the audit is to report stakeholders on internal controls that can lead to proper decisions by the investors. Business strategy and the quality of the auditors' report can affect the weakness of internal control. Because the business strategy enhances the quality of internal control and makes managing better planning for improved internal control. Companies use different business strategies to compete in their chosen industries that require the expertise of auditors in the industry. Therefore, the purpose of this study is to investigate the effect of business strategy on the relationship between auditor's expertise in the industry and internal control with audit quality.

\section{Experimental Background:}

Habib and Hassan (2017) reviewed business strategy, stock price overview, and risk of falling stock prices for companies in Indonesia in 2001-2009. The results indicate that companies with more or less defensive business strategies are at risk of falling stock prices. Also, more stock valuation has a positive (negative) effect on the risk of falling stock prices for firms with a strategy of the defensive business.

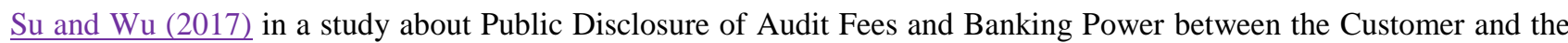
Auditor. Before the public disclosure of compulsory audit fees, it was unlikely that the audit client provided accurate information on the accusation of another company by their auditors. Public disclosure of the fee for employers' access to information reduces the cost of the audit for the auditor's sample and is likely to increase the bargaining power of the employer with the auditors when they negotiate the costs of the audit. The use of both public and property audit fees before and after public disclosure of costs in China was mandatory, we provide evidence-based on previous assumptions. We found that public disclosure of audit fees reinforced the scope of audit fees that would be passed on to costly customers and reduced the ability of auditors to increase audit costs for customers who incurred a little cost. These findings reveal the unintended consequences of the general disclosure provisions of fees, the main reason for this concern was the pricing practices of the audit, which could reduce the independence of the auditor.

Elaoud\&Jarboui (2017) in a study entitled Auditor specialization, accounting information quality, and investment efficiency, emphasized the expertise of auditors in the industry. The results show that the quality of accounting information helps to reduce the investment problem too. Also, the auditor's attributes greatly improve the efficiency of investment, while reducing the issue of less investment. It also showed that the quality of accounting information and the expertise of the auditor of the two mechanisms are to some extent substituted for strengthening the effectiveness of the investment. The quality of audit information is positively related to the efficiency of investment in companies whose accountants are an industrial specialty. In addition, in order to examine the results, this paper studies the causal relationships between the efficiency of investment, auditor's specialty and the quality of accounting information using dynamic equation modeling models.

Qarzai et al. (2017) in a study entitled "Determining the relationship between the characteristics of the audit committee on investment efficiency". The statistical population of the study consisted of 109 companies admitted to Tehran Stock Exchange during the period from 2011 to 2016. The variables used in this research include the investment efficiency as the dependent variable and the characteristics of the audit committee as independent variables and financial leverage, the size of the company as the control variables. The characteristics of the audit committee examined in this study include the size of the Audit Committee and the expertise of the members of the Audit Committee. In this research, the collected data were analyzed using descriptive SPSS-20 software. Then, using appropriate statistical tests and regression analysis using Eviews8 software, the effect of regulatory mechanisms on investment efficiency has been investigated. The results of the research showed that the expertise of the members of the audit committee with the investment performance is a significant and direct relationship, and the size of the audit committee does not have a positive and significant relationship with investment efficiency.

FariGolAfshani and Sadrari (2017) in a research study of the relationship between the industry's specialty of auditors and optional accruals with the role of strategy moderator in the Tehran Stock Exchange. The dependent variable of this research is the optional accruals and independent variable of this research, industry expert's specialty (industry specialization at the level of audit firms) and the moderating variable of this research is a strategic strategy (strategic deviation). Controlling variables include firm size, leverage, asset- The company's long-term leverage ratio - current asset ratio-asset turnover ratios-is a company's loss. The OLS regression analysis has been used in this research. The statistical population of this study is all companies accepted in the Tehran Stock Exchange during the years 1390 to 
1394. Finally, the multivariate regression method is using hybrid data the results of the research show that stronger deviant strategies have a significant effect on the relationship between industrial specification and audit quality.

Moradi (2017) investigated the effect of audit quality on the quality of reporting. The statistical population of the surveyed companies in the Tehran Stock Exchange and the sample included 148 companies accepted during 2006-2011. The results indicate that auditor's period and expertise influence the relationship between free cash flow and reporting quality. Also, auditor's size has a positive and significant effect on the relationship between free cash flow and reporting quality. In sum, the findings show that audit quality has a positive and significant effect on the relationship between free cash flow and reporting quality. Finally, it is recommended that the board structure be approved to issue guidelines that invest cash managers in profitability projects that do not fit their personal interests.

Yuana et al. (2016) investigated the specialty of the auditor in the industry on accruals with respect to the role of the business owner's strategy in the research entitled "the effect of the auditor in the industry on actuality due to the role of the business owner's business. The sample of their research is the Chinese listed companies from 2000 to 2010 . They found that negative connotations between industry professionals and customer discretionary accruals are more prominent when a customer's business strategy is diverted from the normal industry strategy. The results of the research remained valid after controlling the variables and were endorsed against alternative measures of voluntary commitments, auditor expertise in the industry, and strategic deviation. In general, the findings of this research show that the work of the auditor in the industry is not the same for all customers, and customer attributes (such as client strategy) modify the relationship between the industry's expertise in auditing and audit quality. This research helps to increase knowledge about the interaction between customer business strategy and quality of audit.

Hoitash et al., (2016) investigated the expertise of Accountants for Chief Financial Officers. In this study, non-financial criteria such as internal control weaknesses affect the managers' remuneration. Their research focuses on the link between rewards and weaknesses in internal control. The first hypothesis of their research studies the relationship between internal control weaknesses and changes in directors' rewards in companies with strong managerial experience. According to Sarbanes-Oxley law, and that internal controls are under direct managerial responsibility, disclosure of internal control weaknesses indicates a weakness in the performance of the manager, and firms with strong managerial experience after disclosing weaknesses witness a further decline in rewards. Companies that are less experienced in terms of management experience.

Fakhari and Alizade (2016) investigated the characteristics of the company on the weakness of the internal control of the companies accepted in the Tehran Stock Exchange. They document a review of relevant thematic literature, frameworks, and approaches for measuring the components of the features The Company and the weakness of internal control were investigated. The results of their research showed there is a significant relationship between the weakness of internal controls and the firm's performance. Also, there is a significant relationship between the weakness of the domestic controls and the company's age. They found that there is no significant relationship between the weakness of the internal controls and the size of the company and there is a significant relationship between the weakness of internal controls and the company's leverage. In addition, there is no significant relationship between the weakness of internal controls and corporate finance growth.

Shah Wisey et al. (2016) studied the relationship between corporate governance mechanisms with an emphasis on the expertise of the auditor industry with the profit management of companies listed on the Tehran Stock Exchange. The statistical population includes all companies admitted to Tehran Stock Exchange during the period from 1387 to 1393. The findings of the research show that there is a significant relationship between the components of corporate governance, the industry of audit industry and earnings management. The results also show that there is no significant relationship between ownership concentration and profit management. These results also indicate that corporate governance is closely related to profit management, which suggests that the board plays a supervisory role. The results obtained by controlling the size of the company size and the financial leverage remained intact.

Kurdler and Joanne Qalandari (2016) investigated the effect of auditor's specialty on earnings quality and price synchronization in companies admitted to the Tehran Stock Exchange. They found that earnings quality has a negative and significant effect on the price synchronization, and the specialty of the auditor in the industry as a moderating variable strengthens its effect. In other words, the interactive effect of the quality of proficiency of the auditor will reduce the synchronization of stock prices.

Khajavi and Ebrahimi (2015) examined the relationship between auditor size and auditor's expertise in the industry with conservatism. The results of their research showed that regardless of company size, the ratio of debt, profitability, and the ratio of market value to book value of shares, there is a positive and significant relationship between the auditor's size and auditor's specialty in the industry with the company's conservatism. But the relationship between the auditor's tenure and conservatism are negative.

Ahmadpour et al. (2015) investigated the moderating effect of the auditor's specialization on the relationship between the leadership Board of directors and accruals-based profit management. The results of their study showed that the auditor's specialty in industry and the independence of the board of directors had a reverse and significant effect on profit 
management. The results also suggest that the reverse relationship between earnings management and the independence of the board of directors in companies that are audited by industry audit auditors is weaker than those that are audited by non-expert auditors.

Robin and Zhang (2015) examined the relationship between the expertise of the auditors in industry and the risk of falling stock prices in the United States. They found that there is a negative and significant relationship between the expertise of the auditors and the risk of falling stock prices.

Sarwoko\&Agoes (2014) examined the effect of auditors' industrial expertise and auditor's independence on audit quality in research. The results of this study showed that the auditor's expertise in the industry and the independence of the auditor has an impact on the performing of the audit process for fraud detection, and the auditor's specialty in the industry, independence of auditor, and audit process for detecting fraud have a meaningful impact on audit quality. These results show that standard to increase the quality of the audit can be done using the development of competence in the auditor's expertise in the industry and enhance the attitude of the independent auditor and the implementation of adequate audit procedures to detect fraud in the audit financial statements. Report, while defensive companies are aggressively involved in managing profits.

\section{Research Hypotheses}

Considering the theoretical foundations and the background of the research, the research hypotheses have been formulated as follows:

Hypothesis 1: Business strategy affects audit quality.

Hypothesis 2: Business strategy affects the relationship between the weakness of internal control and audit quality.

Hypothesis 3: Business strategy affects the relationship between auditor's expertise in industry and audit quality.

\section{METHODOLOGY}

This research is based on the purpose-oriented classification of applied research. It is also categorized according to the approach of naturalistic (experimental) research and in terms of the purpose of the research is applied (decision-making) and from the perspective of the nature of the research is original research. In terms of the nature of the data, this research is quantitative and the method of research recognition is descriptive and correlated. In this research, the kind of arguments used is inductive and is retrospective in nature. The duration of this cross-sectional study is in the statistical society of the years between 2010 and 2017. Considering that past information of companies is the basis of research, this research is post-event research. The theoretical aspect of this research is categorized in the field of positive research and from this perspective, this research is quasi-empirical research in the field of market capitalism.

\section{Society and statistical sample}

The population of this research was companies accepted in Tehran Stock Exchange from 2010 to 2017. In this research, the sampling method was used purposefully to determine the statistical sample; so that at each stage among all existing companies at the end of 2017, companies that did not have the following conditions eliminated the remaining companies were selected for the test:

- Companies should be active during the period under review.

- The statistical sample does not include banks and financial intermediation.

- Companies whose fiscal year ends by the end of March.

Finally, after sampling, 107 companies were selected to conduct the research hypotheses test.

\section{Data collection method}

In this research, data collection was carried out in two stages. In the first stage, the library method was used to formulate the theoretical foundations of the research, and in the second stage, for collecting the data from the stock exchanges; stock sites and financial information software of the companies were used. Then, Excel was used to prepare the information, so that after extracting information about the variables examined from the sources mentioned, this information was entered into the worksheets created in the software environment and then, the calculations required to achieve the variables examined.

\section{INFORMATION ANALYSIS}

Based on the statistical analysis of data from indicators such as mean, median and standard deviation are used. Also, for testing hypotheses, the regression model of the combined data has been used. To choose from the combination of regression models 31 and the panel data model with constant effects of 32, the F Lemmer test was used. If the F Lemmer test is used to select the combined data method, it is a good idea to complete the Hausman test if the method of panel 
data is selected with fixed effects. The Hausman test is used to determine the use of a constant effect pattern against a random-effects pattern. (Aflatoniand Nikbakht, 2010).

Also, before fitting the pattern, considering the fact that the companies used in this research are related to different industries, a combination of data method is used. As a result, there is a possibility of heterogeneity of variance. To solve this problem, the least-squares regression method was used for pattern matching. In addition, after fitting the pattern, a Watson camera was used to determine the lack of self-correlation in the model's remnants.

\section{Hypothesis test model}

Regarding the theoretical framework and the research background, the research model is multivariate regression. Therefore, the following model is used to perform the test.

$$
\begin{aligned}
& \mathrm{AQ}_{\mathrm{i}, \mathrm{t}}=\alpha_{0}+\alpha_{1} \text { Strategy }_{\mathrm{i}, \mathrm{t}}+\alpha_{2} \text { MWIC }_{\mathrm{i}, \mathrm{t}}+\alpha_{3} \text { STRATEGY } \text { MWIC }_{\mathrm{i}, \mathrm{t}}+\alpha_{4} \text { SPAU }_{\mathrm{i}, \mathrm{t}}+\alpha_{5} \text { STRATEGY } \text { SPAU }_{\mathrm{i}, \mathrm{t}} \\
& +\alpha_{6} \text { AUD }_{i, t}+\alpha_{7} \text { SIZE }_{i, t}+\alpha_{8} \text { GROWTH }_{i, t}+\alpha_{9} \text { LEV }_{i, t}+\alpha_{10} \text { LNAGE }_{i, t}+\alpha_{11} \text { INSOWN }_{i, t}+\varepsilon_{i, t}
\end{aligned}
$$

In the formula:

AQ is Audit Quality, Strategy is Business Strategy, MWIC is Weakness in Internal Control, SPAU is Auditor Expertise in Industry, AUD is Audit Type, INS is Institutional Ownership, Leverage is Financial Leverage, Size is Company Size, GROWTH is company Growth, and LNAGE is Years of Activity for Company. $\mathrm{i}$ is the symbol of the company and $t$ is defined as a year.

\section{Research variables}

\section{Dependent variable}

Audit quality (AQ):

In order to measure it, from the classification guidelines of the audit firms and legal entities under Article 10 of the Securities and Exchange Organization is used. In this instruction, audit firms and legal entities will be divided into four classes according to specific criteria and privileges. First to Fourth Classes. In this instruction, the company is obliged to choose, depending on its class, an independent auditor and a statutory inspector from trusted audit institutions in the same category or class. Institutions will also accept the work of the auditor while complying with the applicable ceilings and regulations. In this research, the audit authority will be used as a representative of the quality of the audit.

\section{Independent research variables}

Internal control quality (MW):

The quality of internal controls is calculated in accordance with previous studies. The following criteria are used to measure internal control quality as an independent variable of internal control weaknesses that are independent of independent auditors comes true. According to the internal control list of the financial reporting agency approved by the Stock Exchange, since 2012, the auditor of the company has been obliged to review the internal control of the company, and in cases which indicate that the internal controls are not followed or not, the disclosure audit report Slowly Hence, if the company has at least one weakness in the system of internal controls, it has a value of 1 , otherwise its value will be zero.

Specialist Auditor's Industry (SPAU): The expertise of the auditor in the industry is defined as the total assets of all the owners of a particular audit institution in a particular industry divided by the total assets of the owners in the industry. Strategic Business Strategy (STRATEGY): To determine the type of strategy of each company, Ittner and Lerker (1997) is used to obtain a combination of five ratios of sales growth, advertising costs to total sales, number of employees For sale, the market value of the company is used in its book value and the ratio of fixed assets to total assets. The system of scoring is that first, companies are divided into five groups based on the four first ratios, from top to bottom, respectively. So that the company that is at the top is the 5th and the lowest-rated company will score 1, and the rest of the companies will be rated in proportion to the respective benchmark. Then the companies are divided into five groups according to the last ratio. This time, the company ranked highest in the quintuple is rated 1, and the company in the bottom ten are rated 5, and the rest of the companies are ranked in the corresponding quintile. In the final step, the points obtained from the two above steps are combined to get the final score of each company. The combination of the sum of five (the sum of the five above ratios) of each company will be between 5 and 25 in one year. Companies with a total score of between 5 and 15 in value will qualify as defensive companies and companies with a total score of between 15 and 25 as prospective companies (Bentley et al., 2013).

\section{Research control variables}

The research control variables are as follows.

Financial leverage (lev); the financial leverage is the sum of the debt divided by the total assets of the company.

Company size (size); natural logarithm of the company's total assets. 
Company Life Logarithm (LNAGE): The logarithm of the years of activity of the company in the stock exchange . Institutional Ownership (INS): To calculate the institutional ownership level, the total amount of shares available to banks and insurance holdings; investment companies; pension funds; capital financing companies; pension funds; capital financing companies; investment funds and organizations; Government institutions and companies are divided into all shares issued by the company and the percentage or amount of institutional ownership is obtained. In the present study, the level of institutional ownership is calculated as follows:

Relation (2)

Institutional ownership= (Total equity available to institutional owners)/ (Total issued shares of the company)

\section{Growth Sales; Growth Sales Ratio;}

Audit type (AUD): A fictitious variable that if the company is considered by an audit firm, the number 1 and otherwise accepts a zero number.

Audit quality means increasing the auditor's effort to detect possible misstatements and misstatements of significance in the financial statements. In fact, audit quality is a regulatory tool that is considered by business owners to enhance the credibility of information and to benefit stakeholders and decision-makers (Fakhari and Alizadeh, 2016).

Auditors understand the nature of the business's internal control system and are aware of the nature of business operations to understand the impact of business strategy on financial statements and thus on the quality of auditing (Khajavi and Ebrahimi, 2015).

The auditor's expertise in the industry makes it possible for clients to provide better and better quality services, as well as provides new insights or solutions to some of the issues and is an effective tool for external stakeholders to understand and use corporate business strategy information (Kurdler and Qalandari, 2016).

The financial leverage of the firm is the cornerstone of contract theory, and auditors enforce the assurance procedures and acceptance of higher-quality audits in accepting or rejecting companies under financial pressure. Because companies that approach or violate financial leverage tend to throw a portion at the auditor's shoulder (Fakhari and Alizadeh, 2016).

Also consider the size of the company, sales growth and the period of activity of the company. Because, according to the theory of political theory, larger corporations are more exposed to the public and to analysts and the media, so the quality of audit information is very important (Kurdler and Qalandari, 2016).

The type of audit that the auditor has a reputation for is trying to provide better quality information and higher audit quality to the capital market because the cost of poor audit quality is too high for a reputable auditor_Fakhari and Alizadeh, 2016).

\section{RESULTS}

Descriptive Statistics, as can be seen, the results of the descriptive statistics of the research variables are shown in table (1)

Table 1: Descriptive statistics of pattern variables *

\begin{tabular}{lllllll}
\hline Symbol & Variable name & average & Middle & Maximum & The minimum & $\begin{array}{l}\text { Standard } \\
\text { deviation }\end{array}$ \\
\hline AQ & audit quality & $0 / 129$ & $0 / 093$ & $0 / 807$ & $0 / 000$ & $0 / 130$ \\
\hline AUD & Type of audit & $0 / 253$ & $0 / 000$ & $1 / 000$ & $0 / 000$ & $0 / 435$ \\
\hline STRATEGY & Business strategy & $0 / 689$ & $1 / 000$ & $1 / 000$ & $0 / 000$ & $0 / 463$ \\
\hline SPAU & $\begin{array}{l}\text { Auditor's expertise } \\
\text { in the industry }\end{array}$ & $0 / 646$ & $1 / 000$ & $1 / 000$ & $0 / 000$ & $0 / 478$ \\
\hline MWIC & $\begin{array}{l}\text { Weak internal } \\
\text { control }\end{array}$ & $0 / 522$ & $1 / 000$ & $1 / 000$ & $0 / 000$ & $0 / 500$ \\
\hline GROWTH & Sales growth & $2 / 600$ & $2 / 235$ & $7 / 625$ & $-0 / 200$ & $1 / 609$ \\
\hline INSOWN & $\begin{array}{l}\text { Institutional } \\
\text { ownership }\end{array}$ & $0 / 115$ & $0 / 095$ & $0 / 352$ & $0 / 010$ & $0 / 081$ \\
\hline LEVERAGE & Financial Leverage & $0 / 687$ & $0 / 657$ & $0 / 863$ & $0 / 01$ & $0 / 077$ \\
\hline LNAGE & $\begin{array}{l}\text { Years of company } \\
\text { activity }\end{array}$ & $3 / 371$ & $3 / 332$ & $4 / 111$ & $2 / 890$ & $0 / 308$ \\
\hline
\end{tabular}

According to the results of descriptive statistics, the variables of the research can be stated that all variable has a normal distribution. 


\section{Inferential statistics}

As discussed in the previous sections, the purpose of this research is to investigate the effect of business strategy on the relationship between auditor's specialization in industry and internal control with audit quality in listed companies in Tehran Stock Exchange. In this regard, based on theoretical foundations, a model consisting of a series of independent variables and control has been developed and will be followed up to be tested. That has a good distribution.

\section{Maneuverability analysis of variables}

In this section, the study of variance or reliability of research variables was studied. Dickey-Fuller test was used to investigate the manes. The results of this test are shown in Table 2. After calculating this statistic, if the calculated statistical value of the table statistics is smaller, the statistical zero assumption is rejected, and the assumption of the existence of the root (unit) root is accepted. Regarding the results of the Maneuverability test, such as the value of Pvalue for all values less than 0.05 , as a result of these variables during the research period in Mana, and variables in each year of the study period are in the level of stagnation.

Table 2: Root Dickey-Fuller Unit Test

\begin{tabular}{llll}
\hline Symbol & Variables & Amount of static statistics & Possibility \\
\hline AQ & audit quality & $-27 / 025$ & $0 / 000$ \\
\hline AUD & Type of audit & $-2 / 755$ & $0 / 002$ \\
\hline STRATEGY & Business strategy & $-2 / 933$ & $0 / 001$ \\
\hline SPAU & Auditor's expertise in the industry & $-4 / 531$ & $0 / 000$ \\
\hline MWIC & Weak internal control & $-3 / 155$ & $0 / 008$ \\
\hline GROWTH & Sales growth & $-32 / 601$ & $0 / 000$ \\
\hline INSOWN & Institutional ownership & $-7 / 426$ & $0 / 000$ \\
\hline LEVERAGE & Financial Leverage & $-118 / 735$ & $0 / 000$ \\
\hline LNAGE & Years of company activity & $-108 / 698$ & $0 / 000$ \\
\hline
\end{tabular}

\section{Residual Normality Test}

One of the important assumptions about the residual is that the distribution of its sentences is normal. The Jarko-test test has been used to test the normality of the residual. According to the results, the probability of the Jarco-Bark test statistic is 0.2654 . Therefore, in the research model, the zero assumption is based on the normalization of the residual. In other words, it can be said that the assumption of the normality of the residual in the research model is established.

Table 3: The results of the normal error statement

\begin{tabular}{llll}
\hline Result & Possibility & Jarco's statistics & Research model \\
\hline Normal being an error & 0.2654 & 74.038 & hypothesis \\
\hline
\end{tabular}

Before model estimation, it is necessary to test the F Lemmer test in order to study the use of a static panel data method in comparison with the combined data method for the above model. The assumptions of this test are as follows:

$H_{0}$ : Normal Combined Data

$H_{1}$ : Panel data with fixed effects

The results of the F lemmer test are shown in Table (4)

Table 4: Results of F Lemer test

\begin{tabular}{lll}
\hline The statistics & Error level & Approved method \\
\hline 4.118 & 0.000 & Panel data \\
\hline
\end{tabular}

As shown in Table 4, the results indicate that $\mathrm{H}_{0}$ is not allowed. As a result of the model, panel data with the fixed effects of the method is preferable. Now it is necessary to continue the Hausman test in order to choose among the methods of panel data with constant effects against the method of panel data with random effects. The assumptions of this test are as follows:
$H_{0}:$ Panel data with random effects
$H_{1}$ : Panel data with fixed effects

The results of the Hausman test are shown in Table (5) 
Table 5: Hausman Test Results

\begin{tabular}{lll}
\hline The statistics & Error level & Approved method \\
\hline 27.682 & 0.0000 & fixed effects
\end{tabular}

As can be seen in Table 5, the results indicate that the assumption $\mathrm{H} 0$ is rejected. As a result of the pattern, panel data with the fixed effects of the method is preferable. In the following, the results of estimating the pattern of research in Fig. 4 are illustrated by the panel data method with constant effects.

\section{Hypothesis test}

The results of the statistics $\mathrm{F}$ (0/0001) also indicate that the model is significant in general. To investigate this selfcorrelation, Watson's camera statistics are used, while the rate is between 1.5 and 2.5 , there is no correlation between the variables, and according to the camera-Watson (0.850) statistics, there is no problem of self-correlation. Also, to test whether there is a heterogeneity variance between the variables, we use the White test and given that White's test statistic (5217/0) which indicates that there is no heterogeneity of variance.

The rate of determination determines the percentage of variation of the dependent variable, which is explained by independent variables and control patterns of the model. In this template, the determination coefficient is approximately $55 \%$, which means that the independent variable and control $63 \%$ explains the variation of the dependent variable. In addition, the results of the adjusted coefficient of the determination indicate that 0.25 of the changes in the quality of the audit were influenced by the independent and control variables of the research throughout the research period.

Table 6: Estimates of the research pattern*

\begin{tabular}{|c|c|c|c|c|c|}
\hline Variable & Symbol & Coefficient & $\begin{array}{l}\mathbf{T} \\
\text { Statistics }\end{array}$ & $\begin{array}{l}\text { Std. } \\
\text { Error }\end{array}$ & Prob. \\
\hline Business strategy & STRATEGY & $0 / 036$ & $0 / 018$ & $2 / 065$ & $0 / 039$ \\
\hline Internal control quality & MWIC & $-0 / 111$ & $0 / 026$ & $-4 / 322$ & $0 / 000$ \\
\hline $\begin{array}{l}\text { Moderating the Business strategy } \\
\text { and Internal control quality }\end{array}$ & STRATEGY*MWIC & $0 / 226-$ & $0 / 071$ & $3 / 171-$ & $0 / 002$ \\
\hline Auditor's expertise in the industry & SPAU & $0 / 114$ & $0 / 054$ & $2 / 112$ & $0 / 035$ \\
\hline $\begin{array}{l}\text { Moderating the Business strategy } \\
\text { and Auditor's expertise in the } \\
\text { industry }\end{array}$ & STRATEGY*SPAU & $0 / 085$ & $0 / 016$ & $5 / 394$ & $0 / 000$ \\
\hline Type of audit & AUD & $0 / 494$ & $0 / 202$ & $2 / 446$ & $0 / 015$ \\
\hline Sales growth & GROWTH & $0 / 005$ & $0 / 002$ & $2 / 578$ & $0 / 010$ \\
\hline Institutional ownership & INSOWN & $-0 / 019$ & $0 / 040$ & $-0 / 472$ & $0 / 637$ \\
\hline Financial Leverage & LEVERAGE & $-0 / 053$ & $0 / 035$ & $-1 / 515$ & $0 / 131$ \\
\hline Years of company activity & LNAGE & $0 / 019$ & $0 / 011$ & $1 / 789$ & $0 / 074$ \\
\hline \multirow[t]{2}{*}{ Company size } & SIZE & $0 / 001$ & $0 / 003$ & $0 / 461$ & $0 / 645$ \\
\hline & $\mathrm{C}$ & $0 / 057$ & $0 / 057$ & $1 / 000$ & $0 / 318$ \\
\hline F-statistic (P-Value) & $.111)$ & & & & \\
\hline R-Squared & & & & & \\
\hline Adjusted R- Squared & & & & & \\
\hline
\end{tabular}

The first hypothesis is to examine the effect of business strategy on the audit quality of listed companies in Tehran Stock Exchange. According to the results obtained in Table 4, the estimation of the research model and the coefficient of business strategy variable (0.036) and its error level (0.039) can be stated that at the acceptable level of error, 5\%, the business strategy variable has a positive and significant effect on audit quality. In line with the result, we can say that the stronger the firm's stroke, the higher the quality of the audit.

The second hypothesis examines the effect of business strategy on the relationship between the weakness of internal control and audit quality of listed companies in Tehran Stock Exchange. According to the results obtained in Table (6), the estimation of the research pattern and the coefficient of the trade strategy variable $(-0.226)$ and its error level (0.000) can be stated that at the acceptable level of error, $5 \%$, the strategy variable Business has a reciprocal and significant effect on the relationship between the weakness of internal control and audit quality.

The third hypothesis examines the impact of the business strategy on the relationship between the auditor's specialty in industry and the audit quality of listed companies in Tehran Stock Exchange; according to the results obtained in Table 6 the estimation of the research pattern and coefficient The trade strategy variable (0.085) and its error level (0.000) can be 
stated that at an acceptable level of $5 \%$, the business strategy variable has a positive and significant effect on the relationship between auditor's specialization in the audit firm's industry.

\section{CONCLUSION}

The purpose of this study was to investigate the effect of business strategy on the relationship between auditor's specialty in industry and internal control with audit quality. The results of the research showed that the business strategy modifies the relationship between the auditor's specialty in industry and internal control with the quality of audit. Also, the business strategy becomes stronger Internal control is especially advisable for those customers who receive the highest returns from the auditor. Therefore, companies are recommended to maintain an organizational structure and audit structure for strategic purposes. Although corporate business strategy may have been planned from the very beginning of the company, for its success, organizations should have a logical internal control structure to meet organizational management objectives in order to increase audit quality. Although business strategies of companies may have been planned from the very beginning of the company, for their success, organizations should have a flexible internal control structure to meet organizational management objectives in order to increase audit quality. Given that capital in the capital market, investors use financial information to make decisions. The greater the quantity and quality of financial information available, the more predictive of future performance and decisions are taken will be more accurate. On the other hand, auditors seek to gain specialization in dealing with companies active in an industry that can differentiate between themselves and other auditors. The existence of this distinction allows auditors to benefit from two lower-cost options and higher quality services instead of having an attractive option for public opinion polls, but in practice, looking to use expert auditors, one of these reasons is to reduce costs. The cost savings resulting from the use of expert auditors are more than the cost of saving other auditors. Because often, auditing takes a large share of the companies in an industry. Another reason is that such auditors are expected to provide better advice and guidance on how to supply and disclose information, and to make better corrective actions to address the problems and omissions of the accounting and financial reporting process. Also, the use of an expert auditor means that the company intends to report more qualitatively than before. Specialist auditors have experiments that other auditors lack, because of their high share of the companies in the industry. Given that the expert's expertise in the industry involves the development of constructive ideas in order to help the builders in creating value-added, and increases the return on investment. Therefore, specialized industry knowledge can be developed through extensive audit experience, Specialist training and more investment in IT. Such research allows auditors to identify factors that affect the quality of auditing services that are associated with asymmetric information loss through their greater ability to identify significant maladjustments.

\section{LIMITATIONS AND STUDY FORWARD}

Considering that the Islamic Republic of Iran needs to attract capital in financial markets, one of the requirements is to increase the transparency of financial statements, which can be investigated by increasing the quality of financial information. The constraint we encountered in our research was the firm business strategy that was lacking in flexibility because of the corporate strategy for adapting to customer and organization structures for impact and value creation. Considering the firmness of the firm's business strategy, the identification of its internal control structure can provide an understanding of the difference between the business strategy and its diversion, which is necessary for the auditor's expertise in the industry. It is proposed to combine business strategy and audit planning we can identify the weakness of the internal control of the system in order to improve the quality of the audit and create value for the stakeholders. For future research, it is suggested to examine the relationship between business strategy and legibility of financial reporting, business strategy and management ability, business strategy and the reputation of the auditor.

\section{REFERENCES}

1. Aflatoni, Abbas and Nikbakht, Leili. (2010). "Econometric Application in Accounting Research, Financial Management and Economic Sciences" First Printing, Tehran, Terme Publishing

2. Ahmadpour, A. Tavaclonia,I and Masomi ,T. (2015). The study of the moderating effect of the auditor's specialty in the industry on the relationship between board management and accruals-based profit management: empirical evidence of companies admitted to the Tehran Stock Exchange. Accounting and Audit Management Knowledge. Volume 4, Number 15, Page 93-106

3. Balsam, S., G. D. Fernando, and A. Tripathy. (2011). the impact of firm strategy on performance measures used in executive compensation. Journal of Business Research, Volume 64, Issue 2, Pages 187-193. https://doi.org/10.1016/j.jbusres.2010.01.006

4. Bentley, K. A., Omer, T. C., \& Sharp, N. Y. (2013). Business strategy, financial reporting irregularities, and auditeffort. Contemporary Accounting Research, 30(2), 780-817. https://doi.org/10.1111/j.1911$\underline{3846.2012 .01174 . x}$

5. Deffond, M. L., and C. S. Lennox. (2015). Do PCAOB Inspections Improve the Quality of Internal Control Audits? Working paper, University of Southern California. https://doi.org/10.2139/ssrn.2574506

6. Dhaliwal, D., C. Hogan, R. Trezevant, and M. Wilkins. (2011). Internal control disclosures, monitoring, and the cost of debt. The Accounting Review 86 (4): 1131-1156. https://doi.org/10.2308/accr$\underline{10043}$ 
7. Dichev, I. D., Graham, J., Harvey, C. R., \& Rajgopal, S. (2013). Earnings quality: Evidence from the field.Journal of Accounting and Economics, 56(2-3), 1-33 (Supplement). https://doi.org/10.1016/j.jacceco.2013.05.004

8. Eilifsen, A., Knechel, W. R., \&Wallage, P. (2001). Application of the business risk audit model: A field study.Accounting Horizons, 15(3), 193-207. https://doi.org/10.2308/acch.2001.15.3.193

9. Elaoud, Assawer\&Jarboui, Anis, (2017). "Auditor specialization, accounting information quality and investment efficiency," Research in International Business and Finance, Elsevier, vol. 42(C), pages 616-629. https://doi.org/10.1016/j.ribaf.2017.07.006

10. Erickson, M. B., W. Mayhew, and W. L. Felix, Jr. (2000). Why do audits fail? Evidence from Lincoln, Journal of Accounting Research, 38 (1): 165-94. https://doi.org/10.2307/2672927

11. Fakhari, H. and Alizadeh, M. (2016). Investigating Economies and Economic Outcomes Optional Disclosure of Internal Control weaknesses of accepted companies in Tehran Securities Exchange, the first international conference of business intelligence and business intelligence paradigms. $p 16$

12. FariGolAfshani, R. Sadrari,M,A. (2017), relationship between the industry's specialty of auditors and optional accruals with the role of strategy moderator in Tehran Stock Exchange, Second International Management and Accounting Conference, Sari,Iran. https://www.civilica.com/Paper-MANAGECONF02MANAGECONF02_1049.html

13. Gramling, A.,\& Stone, D. (2001). Audit firm industry expertise: A review andsynthesis of the archival literature. Journal of Accounting Literature, 20, 1-27

14. Habib, A., and Hasan, M. M. (2017). Business strategy, overvalued equities, and stock price crash risk. Research in International Business and Finance, 39, 389-405. https://doi.org/10.1016/j.ribaf.2016.09.011

15. Harmon, P. (2003). Business Process Change. Morgan Kaufman Publishers. San Francisco.

16. Higgins, D., T. C. Omer, and J. D. Phillips. (2015). The Influence of a Firm's Business Strategy on its Tax Aggressiveness. Contemporary Accounting Research 32 (2): 674-702. https://doi.org/10.1111/1911$\underline{3846.12087}$

17. Hoitash, R., Hoitash, U., and Kurt, A., (2016). Do Accountants Make Better Chief Financial Officers? Journal of Accounting and Economics61: 414-432. https://doi.org/10.1016/j.jacceco.2016.03.002

18. Ittner, C., and Larcker, D. (1997). Product Development Cycle Time and Organizational Performance. Journal of Marketing Research, 34 (1) , 13-23. https://doi.org/10.1177/002224379703400102

19. Johnstone, K., C. Li, and K. Rupley, (2010), Changes in corporate governance associatedwith the revelation of internal control material weakness and their subsequent tremediation, Contemporary Accounting Research 27, 1-53. https://doi.org/10.1111/j.1911-3846.2010.01037.x

20. Kathleen M. Hamm,(2018), Quality Control: The Next Frontier, https://pcaobus.org/News /Speech/Pages/hamm-quality-control-next-frontier.aspx

21. Khajavi,S and Ebrahimi,M. (2015) Audit and Conservatism Quality: Evidence from the Companies Accepted in Tehran Stock Exchange, Journal of Accounting and Audit Research, Volume : 7 - Issue : 27 - Page:4 -19.

22. Kinney Jr., W. R., and M. L. Shepardson. (2011). Do control effectiveness disclosures require SOX 404 (b) internal control audits? A natural experiment with small US public companies. Journal of Accounting Research 49 (2): 413-448. https://doi.org/10.1111/j.1475-679X.2011.00400.x

23. Krishnan, G. V. (2003). Does Big 6 auditor industry expertise constrain earnings management? Accounting Horizons, 17, 1-16 (Supplement). https://doi.org/10.2308/acch.2003.17.s-1.1

24. Kurdler, A E and JavanQalandari.M, (2016). Effect of auditor's specialty on earnings quality and price synchronization. Accounting and auditing reviews. Volume 23, Number 2, Pages 137-154.

25. Michelon, G., Bozzolan, S. and Beretta, S. (2015), Board monitoring and internal control system disclosure in different regulatory environments, Journal of Applied Accounting Research, 16 (1), 138-164. https://doi.org/10.1108/JAAR-03-2012-0018

26. Miller,T. Cipriano,M. Ramsay,R, (2012) "Do auditors assess inherent risk as if there are no controls?", Managerial Auditing Journal, Vol. 27 Issue: 5, pp.448-461, https://doi.org/10.1108/02686901211227931

27. Miettinen, J. (2014). Audit quality and the relationship between auditee's agency problems and financial information quality: Research proposal, Available online at: http://www.researchgate.net/publication/rorrマqq५o_Audit_quality_and_the_relationship_between_auditee's_ agency_problems_and_financial_information_quality_Research_proposal.

28. Moradi, Dariush (2017). Study of the Effect of Audit Quality on Reporting Quality, National Conference on Modern Research in Management, Economics and Humanities, Kazeroun, Azad University, Kazeroon Branch.

29. Newton, N. J., J. S. Persellin, D. Wang, and M. S. Wilkins. (2016). Internal control opinion shopping and audit market competition. The Accounting Review 91 (2): 603-623. https://doi.org/10.2308/accr-51149

30. Qarzai, F. Ghasemi ,G and Pour Ehtesham,M.(2017), Determining the relationship between the characteristics of the audit committee on investment efficiency, The first national conference on modern research in Iran and the world in management, economics and accounting, and humanities, Sabzevar, Iran, https://www.civilica.com/Paper-MEAHBTM04-MEAHBTM04_186.html 
31. Robin and Zhang (2015) Do Industry-Specialist Auditors Influence Stock Price Crash Risk? AUDITING: A Journal of Practice \& Theory, Vol. 34, No. 3, pp. 47-79. https://doi.org/10.2308/ajpt-50950

32. Sarwoko and Agoes, (2014), An Empirical Analysis of Auditor's Industry Specialization, Auditor's Independence and Audit Procedures on Audit Quality: Evidence from Indonesia, Procedia - Social and Behavioral Sciences, Volume 164, Pages 271-281. https://doi.org/10.1016/j.sbspro.2014.11.077

33. Shah wisey, Farhad; FarhadMirzaee and Abdollah Abdi Baraftabi (2016), Investigating the Relationship between Corporate Governance Mechanisms with Emphasis on Audience Industry Expertise with Profit Management of Companies Accepted in Tehran Stock Exchange, Fourth International Conference on Applied Research in Applied and Management, Tehran, ShahidBehshti.

34. SuXijia and Wu Xi. (2017) Public Disclosure of Audit Fees and Bargaining Power between the Client and Auditor: Evidence from China, The International Journal of Accounting, Volume 52, Issue 1, Pages 64-76, https://doi.org/10.1016/j.intacc.2017.01.001

35. Verschoor, C.C. (2002), “Audit committees focus on risk management”, Internal Auditing, July/August, pp. 27-32.

36. Yuana, R., Chengb, Y., \& Yea, K. (2016). Auditor Industry Specialization and Discretionary Accruals: The Role of Client Strategy. The International Journal of Accounting, 51(2), 217-239 . https://doi.org/10.1016/j.intacc.2016.04.003

37. Zhang, Y., J. Zhou, and N. Zhou. (2007). Audit committee quality, auditor independence, and internal control weaknesses. Journal of Accounting and Public Policy, 26 (3): 300-327. https://doi.org/10.1016/j.jaccpubpol.2007.03.001 